December 2015

\title{
Editorial, RadioDoc Review, Volume Two, Issue Two, 2016
}

Siobhan McHugh

University of Wollongong

Follow this and additional works at: http://ro.uow.edu.au/rdr

Part of the Audio Arts and Acoustics Commons, and the Radio Commons

\section{Recommended Citation}

McHugh, Siobhan, Editorial, RadioDoc Review, Volume Two, Issue Two, 2016, RadioDoc Review, 2(2), 2015. doi:10.14453/rdr.v2i2.9

Research Online is the open access institutional repository for the University of Wollongong. For further information contact the UOW Library: research-pubs@uow.edu.au 


\title{
Editorial, RadioDoc Review, Volume Two, Issue Two, 2016
}

\author{
Abstract \\ Overview of articles reviewed in fourth issue of RadioDoc Review
}

Keywords

podcasting, audio storytelling, subtitled audio 


\section{Editorial, RadioDoc Review Volume Two, Issue Two}

This issue of RadioDoc Review continues to explore diverse cultural and regional production of excellent audio features. We critique audio works from Germany, Norway, Australia, the US, along with one transnational offering, Sensa Parole, which was made by a Belgian, recorded in Paris and part-produced in the US. Our reviewers likewise offer deeply varied perspectives, from Denmark, Sweden, Australia and Germany. This broad range of creative works, analysed by reviewers who are acclaimed audio producers and/or scholars, extends the canon of carefully crafted, resonant audio features being amassed by the international community of audio makers and academics that comprises RadioDoc Review.

Themes addressed in the audio works range from affectionate portraits of vulnerable individuals to the scarifying impacts of war in Syria, torture in Guantanamo Bay and child sexual abuse. US producer Gregory Whitehead's 'performance documentary' On the Shore Dimly Seen catalogues 24 hours in the life of an anonymous Guantanamo Bay detainee. Distinguished German radio drama producer Gotz Naleppa reveals its terrible power, describing it as 'torture to listen to this cantata about torture. I write this with deep respect and admiration for this work.' Australian scholar Virginia Madsen describes how in the piece, 'monstrous versions of lost souls in limbo escaped into the air fractured screams, glottal splats, and plosive ventings half-asphyxiated...'

The Hacker Syndrome tells the story of how one German tech wizard gets heavily involved with activists in the Arab Spring. Awardwinning producer Martin Johnson from Sweden notes in his review the difficulties of making an audio feature whose protagonist is relatively emotionless. In this complex piece, the narrative tension builds slowly but assuredly. The Norwegian feature, Still Glowing Strong by Sindre Leganger, also unfolds at a gentle pace, but here the characters evoke deep emotions. The protagonist is an old man who believes he has invented an everlasting battery, his gift to the world. Celebrated Danish producer Lisbeth Jessen was touched 'by its quiet strength... the language, the story, and the composition...the corner of reality told by a Norwegian temperament.' Australian documentary-maker Maree Delofski also enjoyed this 'elegant and poetic documentary about a dreamer... From the outset, the minimalist music and Leganger's 
beautifully written narration set up the tone of the documentarygentle, respectful, restrained, occasionally melancholic yet never maudlin.' Delofski notes how Leganger's observational recording technique compares to what ethnographic filmmaker and theorist Jean Rouch has referred to as the camera provocateur - "the idea that film recording technologies must necessarily affect the reality they are 'capturing'. So too with audio recording technologies."

The microphone is also the leading player in the next two features critiqued. Eminent Australian feature maker Robyn Ravlich celebrates Belgian producer Katarina Smets as an 'acoustic flaneur', who meanders the streets of Paris looking for some chance encounter or irrational meeting. Her Sensa Parole (Without Words) is on the surface a slight piece about Smets' meeting with a homeless woman who maintains a dignified existence on the banks of the Seine. But there is more to it: ' 1 began to hear some rather subtle, touching things to do with communication and marginality; the application of delicate skills of composition and construction; and a finely written and spoken narration, weaving a thread between elements of gossamer. Artlessness now seemed more artful.'

Miyuki Jokiranta, presenter of the Australian national broadcaster's Soundproof program on RN, deftly unpicks the seven-minute feature, $A$ Kiss, by Canadian Kaitlin Prest, host of The Heart podcast. 'Podcasts slip the bonds of traditional broadcast formats, editorial guidelines, and their time constraints. A story takes as long or as short as it needs, as is the case with $A$ Kiss, a quick seven minute dip in the shared psyche of Kaitlin and her former lover, Kyle, who after three years of being separated, now find themselves in Kaitlin's bedroom on a sun-drenched afternoon, in the air a question - will they kiss?' Much of this feature's strength comes from its careful sound design. 'As the emotional complexities of the afternoon unfold, the voices start to shift between left and right, between foreground and background. The narrators are subverted by the observers of the action and talk over not only each other, but also themselves.'

The last feature reviewed in this issue is the troubling The Storm, by Australian producer Kirsti Melville, in which she tells the story of the child sexual abuse suffered by 'Erik', her former partner and the father of her son. They remain close friends and their relationship is central to 
how the story is told and to its gut-wrenching impact. Australian radio scholar Mia Lindgren analyses this award-winning documentary 'through a lens of personal and confessional audio journalism, drilling deep into lived experiences of the human condition. It highlights the ethical and emotional challenges of the journalist being a character of the story and the complexities of producing radio documentaries that document human trauma without exploiting the subject.'

Finally, this issue, RadioDoc Review is delighted to announce a collaboration with Radio Atlas, created by Falling Tree Productions producer Eleanor McDowall in the UK as 'an English-language home for subtitled audio from around the world'. Radio Atlas (radioatlas.org) takes an innovative approach to subtitling, ensuring that the listener sees the translation in sync with the audio, which greatly enhances the appreciation of the work. Please see the separate links to RDR-critiqued works Still Glowing Strong (Norwegian) and Who Killed Lolita (French), the first two offerings.

I write this editorial from the Global Editors Network media summit in Vienna, where I am hosting a panel on podcasting with industry figure Sarah van Mosel (CEO of Swedish ACAST podcast aggregator) and podcast researcher Vanessa Quirk, who authored a Guide to Podcasting (2015) for the Tow Center for Digital Journalism at Columbia University. Interest in podcasting has grown since last year's session, where I spoke alongside the producer of Serial, Dana Chivvis. For the latest academic research on trends in podcasting, see The Radio Journal: International Studies in Broadcast and Audio Media, Vol 14 (2). For a brief overview, see my article this month in The Conversation, "Podcast Hosts: the new Media Stars?" at http://theconversation.com/podcast-hosts-the-newmedia-stars-59987 Podcasting is gaining new converts to audio storytelling day by day, both as listeners and audio makers. Just this month, American author and social scientist Malcolm Gladwell launched a podcast via Panoply called Revisionist History, commenting to a New York audience that with audio, 'what opens up to you is emotion'. At RadioDoc Review, we've all known that for a very long time - but it's good to see that writers and journalists in other formats are beginning to appreciate the intimacy and power of the medium.

Siobhan McHugh,

Founding Editor, RadioDoc Review, Vienna, 16 $6^{\text {th }}$ June 2016 